\title{
Faktor - faktor yang mempengaruhi lamanya mencari pekerjaan di Desa Betung Bedarah Timur Kecamatan Tebo Ilir
}

\author{
Jumairi; *Yulmardi; Junaidi \\ Prodi Ekonomi Pembangunan Fak.Ekonomi dan Bisnis Universitas Jambi \\ *Email korespodensi: yulmardiedy@yahoo.co.id
}

\begin{abstract}
The purpose of the study was to analyze and study the factors influencing job search in Betung Bedarah Timur Village, Tebo Ilir District. The analytical method used in this research is descriptive qualitative analysis and quantitative analysis. Data processing is performed using multiple linear regression. Based on the results of the study using statistics, that is to see the comparison of the silmultan test which are all variables of age, education, and gender together against the duration of unemployment in Betung Bedarah Timur Village, Tebo Ilir District, Tebo Regency. If partially tested the variables that have participation and education have a significant effect on the duration of unemployment in Betung Bedarah Timur Village, Tebo Ilir Subdistrict, Tebo Regency, while the income and gender variables are not significant on the duration of unemployment in Betung Bedarah Timur Subdistrict, Tebo Ilir Subdistrict, Tebo Regency.
\end{abstract}

Keywords: Social and Economic Conditions, Unemployment, Old Unemployed

\begin{abstract}
Abstrak
Tujuan penelitian untuk menganalisis dan mengetahui faktor - faktor yang mempengaruhi lamanya mencari pekerjaan di Desa Betung Bedarah Timur Kecamatan Tebo Ilir. Metode analisis yang digunakan dalam penelitian ini analisis deskriptif kualitatif dan analisis kuantitatif. Pengolahan data dilakukan dengan menggunakan regresi linier berganda. Berdasarkan hasil penelitian dengan menggunakan statistik yaitu untuk melihat pengaruh secara uji silmultan yaitu semua variabel usia, gaji, pendidikan dan jenis kelamin secara bersama - sama berpengaruh terhadap lamanya menganggur di Desa Betung Bedarah Timur Kecamatan Tebo Ilir Kabupaten Tebo. Jika di uji secara parsial variabel yang memiliki pengaruh adalah usia dan pendidikan berpengaruh signifikan terhadap lamanya menganggur di Desa Betung Bedarah Timur Kecamatan Tebo Ilir Kabupaten Tebo, sedangkan variabel gaji dan jenis kelamin tidak berpengaruh signifikan terhadap lamanya menganggur di Desa Betung Bedarah Timur Kecamatan Tebo Ilir Kabupaten Tebo.
\end{abstract}

Kata kunci: Kondisi sosial dan ekonomi, Pengangguran, Lama menganggur

\section{PENDAHULUAN}

Pembangunan ekonomi pada hakekatnya adalah serangkaian usaha kebijaksanaan yang bertujuan untuk meningkatkan taraf hidup masyarakat memperluas kesempatan kerja dan mengarahkan pembagian pendapatan secara merata. Dalam pembangunan ekonomi Indonesia kesempatan kerja masih menjadi masalah utama Amir 
(2007). Hal ini timbul karena adanya kesenjangan atau ketimpangan dalam mendapatkannya. Pokok dari permasalahan ini bermula dari kesenjangan antara pertumbuhan jumlah angkatan kerja disatu pihak dan kemajuan berbagai sektor perekonomian dalam menyerap tenaga kerja dipihak lain (Sukirno, 2006).

Faktor-faktor tingkat pengangguran dalam aspek perekonomian adalah pertumbuhan ekonomi, pertumbuhan penduduk dan tingkat partisipasi angkata kerja Mankiw (2006). Melalui tingkat pengangguran dapat dilihat tingkat kesejahteraan masyarakat serta tingkat distribusi pendapatan. Pengangguran terjadi sebagai akibat dari tingginya pertumbuhan penduduk dan melemahnya perekonomian yang disebabkan oleh tingkat inflasi maka tingkat perubahan angkatan kerja yang tidak diimbangi dengan penyerapan tenaga kerja yang disebabkan karena rendahnya pertumbuhan penciptaan lapangan kerja (Mulyadi, 2003).

Pengangguran merupakan masalah disetiap daerah khusus pada Kabupaten Tebo dalam mengatasi masalah pengangguran, merupakan masalah yang sangat kompleks karena mempengaruhi sekaligus dipengaruhi oleh beberapa faktor yang saling berinteraksi mengikuti pola yang tidak selalu mudah dipahami. Apabila pengangguran tersebut tidak segera diatasi maka dapat menimbulkan kerawanan sosial dan berpotensi mengakibatkan kesenjangan Novianti (2018). Pengangguran di perdesaan sejak tahun 2014 sampai dengan 2017 mengalami penurunan pengangguran terbuka mengalami fluktuasi tahun 2014 - 2017 yaitu rata-rata sebesar 2,44 persen. Besarnya tingkat pengangguran di Kabupaten Tebo akan berdampak terhadap pembangunan daerah. Kuncoro (2006) Akses pasar tenaga kerja tercermin dari tertinggalnya Tingkat Partisipasi Angkatan Kerja (TPAK), Tingkat Kesempatan Kerja (TKK), Employment to Population Ratio (EPR), Tingkat Pengangguran Terbuka (TPT), tingkat pekerja tidak penuh, paruh waktu, dan setengah menganggur. Ketertinggalan dalam akses pasar tenaga kerja mencerminkan bahwa peluang usaha untuk bekerja lebih rendah. Kondisi perlambatan dalam meningkatkan akses pasar kerja ini menunjukkan bahwa perlu suatu program atau kebijakan sosial yang lebih aktif mendorong peran masyarakat perdesaan dalam memasuki pasar tenaga kerja (Simanjuntak, 2001).

Biasanya permintaan akan tenaga kerja itu dipengaruhi oleh perubahan tingkat upah dan faktor-faktor lain yang mempengaruhi permintaan hasil. Hal ini berkaitan dengan biaya produksi yang dikeluarkan oleh pihak perusahaan, semakin tinggi upah atau gaji yang diberikan maka akan mengakibatkan semakin sedikit permintaan akan tenaga kerja begitu juga sebaliknya, hal ini sesuai dengan hukum permintaan (Sumarsono, 2003). Jumlah lapangan pekerjaan yang tersedia tidak sebanding dengan jumlah pencari kerja yang ada, pencari kerja di Desa Betung Bedarah Timur terus ada setiap tahunnya akan tetapi perbandingan antara pencari pekerjaan yang lebih besar dengan jenis pekerjaan yang terdaftar, pada tahun 2014 pencari kerja sebanyak 504 jiwa dengan jenis pekerjaan yang terdaftar hanya 89 lapangan kerja akan tetapi yang terserap hanya 404 jiwa, pada tahun 2017 mengalami penurunan pencari kerja sebanyak 339 jiwa dengan jenis pekerjaan terdaftar sebanyak 77 lapangan kerja yang mampu menyerap sebanyak 299 jiwa (Kecamatan Tebo Ilir, 2018). Hal ini diketahui bahwa persediaan lapangan kerja yang terdaftar mengalami penurunan maka mampu mengurangi jumlah pekerjanya untuk menekan biaya produksi dan adanya ketidak seimbangan antara jumlah pencari kerja yang ada di Desa Betung Bedarah Timur dengan jumlah lowongan kerja yang tersedia sehingga hal tersebut menimbulkan pengangguran.

Kecenderungan meningkatnya angka penganguran telah menjadikan masalah yang makin serius. Kemungkinan ini disebabkan bahwa semakin tinggi tingkat pendidikan yang ditamatkan maka makin tinggi pula aspirasi untuk mendapatkan 
kesempatan kerja akan tetapi dalam meningkatnya angkatan kerja tidak diimbangi dengan persediaan lapangan kerja, maka akan terciptanya pengangguran terutama pengangguran terdidik (Yuliati, 2011). Maka proses untuk mencari kerja yang lebih lama pada kelompok pencari kerja terdidik yang disebabkan oleh terlambatnya perkembangan informasi di pasar kerja, dan mereka memilih pekerjaan yang diminati dan menolak pekerjaan yang tidak sesuai. Banyak sekali masalah-masalah sosial yang bersifat negatif timbul akibat meningkatnya pengangguran. Dari fenomena inilah yang mendorong peneliti untuk mengamati lebih lanjut tentang "Faktor - faktor yang mempengaruhi lamanya mencari pekerjaan di Desa Betung Bedarah Timur Kecamatan Tebo Ilir.

\section{METODE}

\section{Jenis dan sumber data}

Untuk menjawab rumusan masalah pertama yaitu untuk menganalisis dan mengetahui kondisi karakteristik sosial dan ekonomi responden penduduk di Desa Betung Bedarah Timur Kecamatan Tebo Ilir, digunakan metode analisis deskriftif (Table Frekuensi) Gujarati (2003).

\section{Metode analisis data}

\section{Ordinary least square (OLS)}

Untuk menjawab rumusan masalah kedua yaitu menganalisis dan mengetahui faktor - faktor yang mempengaruhi lamanya mencari pekerjaan di Desa Betung Bedarah Timur Kecamatan Tebo Ilir menggunakan model regresi linear berganda dengan metode kuadrat terkecil atau Ordinary Least Square (OLS). Model yang digunakan dalam penelitian ini dijabarkan dalam fungsi sebagai berikut Sugiyono (2016):

Keterangan :

$$
\mathrm{Y}=\beta_{0}+\beta_{1} U+\beta_{2} P K+\beta_{3} P D D+\beta_{4} J K+e
$$

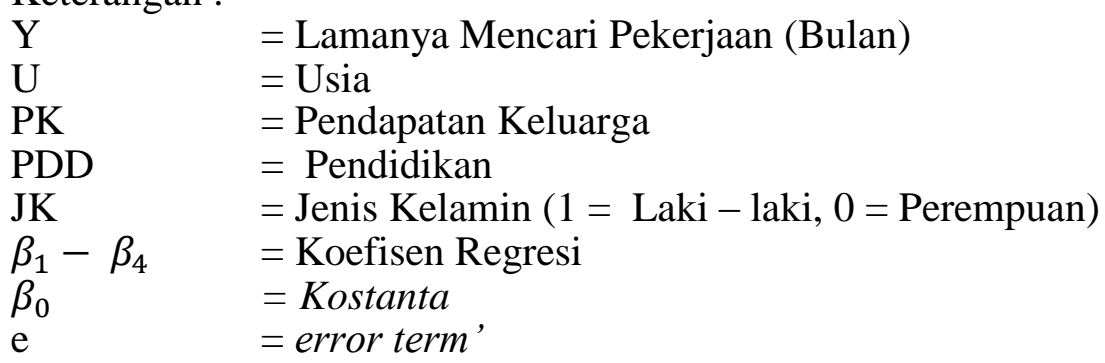

\section{HASIL DAN PEMBAHASAN}

Berdasarkan hasil penelitian dari 75 responden maka dapat diketahui kondisi sosial dan ekonomi yang mempengaruhi fertilitas di Desa Betung Bedarah Timur Kecamatan Tebo Ilir Kabupaten Tebo. Adapun untuk menentukan sosial dan ekonomi karakteristik penduduk yang menggambarkan beberapa kondisi sosial pada penelitian ini, meliputi umur, pendidikan, status pekerjaan, jenis lapangan pekerjaan, dan pendapatan.

\section{Umur}


Umur responden yang menjadi sampel dalam penelitian ini. Pada umumnya usia seorang mempengaruhi bagaimana seseorang tersebut mampu untuk bekerja dengan golongan umur 15 tahun keatas. Untuk melihat kelompok umur dalam penelitian ini yaitu penduduk di Desa Betung Bedarah Timur dapat dilihat pada tabel di bawah ini:

Tabel 1. Distribusi responden menurut umur di Desa Betung Bedarah Timur

\begin{tabular}{ccc}
\hline Umur (Tahun) & Jumlah (Orang) & Persentase (\%) \\
\hline $22-25$ & 30 & 40,00 \\
$26-30$ & 30 & 40,00 \\
$31-35$ & 7 & 9,33 \\
$36-40$ & 6 & 8,00 \\
$>41$ & 2 & 2,67 \\
\hline Jumlah & $\mathbf{7 5}$ & $\mathbf{1 0 0 , 0 0}$ \\
\hline
\end{tabular}

Sumber : Data diolah, 2019

Berdasarkan Tabel Tabel 1 di atas dapat dilihat bahwa usia responden di Desa Betung Bedarah Timur usia 22 - 25 tahun sebanyak 30 orang atau sebesar 40,00 persen, pada usia 26 - 30 tahun sebanyak 30 orang atau sebesar 40,00 persen, pada usia $31-35$ tahun sebanyak 7 orang atau sebesar 9,33 persen, pada usia 36 - 40 tahun sebanyak 2 orang atau sebesar 8,00 persen, dan pada usia lebih dari 41 tahun sebanyak 2 orang atau sebesar 2,67 persen. Berdasarkan hasil survey menunjukan responden paling banyak terdapat pada usia 22 - 25 tahun dan 26 - 30 tahun yang berjumlah 30 orang atau sebesar 40,00 persen, usia responden tersebut masuk kedalam penduduk yang produktif mampu menghasilkan pendapatan sendiri dengan bekerja, banyaknya responden pada usia tersebut di karenakan pada saat pengambilan sampel kebanyakan penduduk berstatus pekerjaan buruh dibayar.

\section{Pendidikan}

Tingkat pendidikan disini diartikan sebagai jenjang pendidikan terakhir yang telah ditamatkan oleh para responden di Desa Betung Bedarah Timur Kecamatan Tebo Ilir Kabupaten Tebo. Adapun jenjang pendidikan dalam penelitian ini dikelompokkan yaitu pendidikan tamat sekolah menengah atas, tamat diploma dan tamat sarjana. Untuk mengetahui jumlah dan persentase responden sebagai dalam penelitian menurut pendidikan yang ditamatkan di Desa Betung Bedarah Timur dapat dilihat pada tabel:

Tabel 2. Distribusi responden menurut tingkat pendidikan di Desa Betung Bedarah Timur

\begin{tabular}{ccc}
\hline Pendidikan & Jumlah (orang) & Persentase (\%) \\
\hline SMA/ Sederajat & 42 & 56,00 \\
Diploma I & 3 & 4,00 \\
Diploma III & 6 & 8,00 \\
Sarjana & 24 & 32,00 \\
\hline Jumlah & $\mathbf{7 5}$ & $\mathbf{1 0 0 , 0 0}$ \\
\hline
\end{tabular}

Sumber : Data diolah, 2019

Berdasarkan Tabel 2 di atas dapat dilihat bahwa dari 75 responden dalam penelitian ini dengan tingkat pendidikan terakhir responden pada tamat SMA sederajat sebanyak 42 orang atau 56,00 persen, tamat diploma I sebanyak 3 orang atau 4,00 persen, tamat diploma III sebanyak 6 orang atau 8,00 persen dan tamat sarjana sebanyak 
24 orang atau 32,00 persen. Pendidikan responden di Desa Betung Bedarah Timur banyak terdapat pada pendidikan yang ditamatkan pada tingkat sekolah atas dengan jumlah 42 orang atau sebesar 56,00 persen, banyaknya responden di Desa Betung Bedarah Timur yang pendidikan terakhinya SMA dikarenakan, hanya bekerja sebagai buruh maupun petani yang tidak mementingkan pendidikan, rendahnya kualitas sumber daya manusia ini disebabkan karena penduduk di Desa Betung Bedarah Timur memiliki perekonomian yang cukup rendah, oleh karena itu mereka bekerja untuk bisa meningkatkan dan memenuhi kebutuhan hidup keluarganya.

\section{Status pekerjaan}

Status pekerjaan yang dimaksud disini adalah jenis pekerjaan dari responden di Desa Betung Bedarah Timur yang terdiri dari bebas non pertanian, bebas pertanian, berusaha sendiri, buruh tetap dan buruh tidak tetap. Untuk melihat status pekerjaan dapat dilihat pada Tabel.

Tabel 3. Distribusi menurut status pekerjaan responden di Desa Betung Bedarah Timur

\begin{tabular}{ccc}
\hline Pekerjaan & Jumlah & Persentase \\
\hline Buruh Pekerja di Bayar & 32 & 42,66 \\
Buruh Pekerja Tetap & 34 & 45,33 \\
Buruh Pekerja Tidak Tetap & 9 & 12,00 \\
\hline Jumlah & $\mathbf{7 5}$ & $\mathbf{1 0 0 , 0 0}$
\end{tabular}

Sumber : Data diolah, 2019

Berdasarkan Tabel 3 di atas menunjukkan bahwa penduduk responden di Desa Betung Bedarah Timur status pekerjaan berdasarkan criteria SUSENAS ada 5 status pekerjaan, yaitu pada buruh dibayar 32 orang atau sebesar 42,66 persen, pada status pekerjaan sebagai buruh tetap sebanyak 34 orang atau sebesar 45,33 persen, dan responden status pekerjaan buruh tidak tetap sebanyak 9 orang atau 12,00 persen. Responden banyak terdapat pada status pekerjaan sebagai buruh tetap yaitu mencapai 34 orang atau sebesar 45,33 persen, banyaknya responden yang bekerja sebagai pegawai dan karyawan dikarenakan memiliki pendidikan yang cukup tinggi.

\section{Jenis lapangan usaha}

Urutan jenis pekerjaan diurutkan pada tingkat produktifitas kerja, mulai dari yang paling produktif sampai dengan yang tidak produktif. Selain itu, jenis pekerjaan seringkali dihubungkan dengan tingkat pendidikan, keterampilan dan jumlah jam kerja untuk mengetahui dimana ada setengah pengangguran dan tempat tinggal maupun mobilitas pekerjaan dengan menghubungkan jenis pekerjaan pada tahun - tahun sebelumnya. Berdasarkan data survei yang di dapat dari responden di Kelurahan Pakuan Baru Kecamatan Jambi Selatan berdasarkan Tabel 4 menunjukkan bahwa dari 75 responden sebagian besar mereka bekerja sebagai buruh yaitu 19 orang atau 25,33 persen, bekerja sebagai guru sebanyak 10 orang atau 13,33 persen, bekerja sebagai karyawan swasta sebanyak 16 orang atau 21, 33 persen, sebagai bekerja kesehatan sebanyak 5 orang atau 6,66 persen, bekerja sebagai kontraktor sebanyak 3 orang atau 4,00 persen, bekerja sebagai PNS sebanyak 10 orang atau 13,33 persen, bekerja sebagai security sebanyak 8 orang atau 10,66 persen, bekerja sebagai supir sebanyak 2 orang atau 2,66 persen, dan bekerja sebagai TNI dan Polri sebanyak 2 orang atau 2,66 persen. Berbagai macam jenis pekerjaan yang menjadi responden lebih banyak sebagai buruh.

Tabel 4. Distribusi menurut jenis pekerjaan responden di Desa Betung Bedarah Timur 


\begin{tabular}{|c|c|c|}
\hline Pekerjaan & Jumlah & Persentase \\
\hline Buruh & 19 & 25,33 \\
\hline Guru & 10 & 13,33 \\
\hline Karyawan Swasta & 16 & 21,33 \\
\hline Kesehatan & 5 & 6,66 \\
\hline Kontraktor & 3 & 4,00 \\
\hline PNS & 10 & 13,33 \\
\hline Security & 8 & 10,66 \\
\hline Supir & 2 & 2,66 \\
\hline TNI/Polri & 2 & 2,66 \\
\hline Jumlah & 75 & 100,00 \\
\hline
\end{tabular}

Sumber : Data diolah, 2019

\section{Pendapatan}

Kondisi ekonomi dalam penelitian ini meliputi dapat dilihat dari pendapatan yang diterima oleh responden selama 1 bulan. Banyaknya pendapatan kisaran Rp. 2.100.000 - 3.000.000 hal ini dikarenakan responden banyak sebagai buruh tidak tetap. Besarnya pendapatan dalam memenuhi kebutuhan keluarganya ini menunjukan besarnya kemampuan kepala rumah tangga dalam memenuhi kebutuhan rumah tangga, dikarenakan bagi responden yang bekerja sebagian bekerja sebagai buruh perusahaan maupun buruh rumah tangga (seperti menjadi supir pribadi, tani, dan bekerja serabutan). Angka rata-rata dari besarnya pendapatan yang diterima oleh responden di Desa Betung Bedarah Timurdalam 1 bulan adalah sebesar Rp 2.548.000,-. Untuk melihat jumlah pendapatan dapat dilihat pada tabel:

Tabel 5. Distribusi pendapatan responden di Desa Betung Bedarah Timur

\begin{tabular}{ccc}
\hline Pendapatan (Rupiah) & Jumlah & Persentase \\
\hline $1.000 .000-2.000 .000$ & 26 & 34,66 \\
$2.100 .000-3.000 .000$ & 38 & 50,66 \\
$3.100 .000-4.000 .000$ & 9 & 12,00 \\
$4.100 .000-5.000 .000$ & 2 & 2,66 \\
\hline Jumlah & $\mathbf{7 5}$ & $\mathbf{1 0 0 , 0 0}$ \\
\hline & Rata-Rata $=\mathbf{2 . 5 4 8 . 0 0 0}$ & \\
\hline
\end{tabular}

Sumber : Data diolah, 2019

Berdasarkan Tabel 5 di atas menunjukkan bahwa dari 75 responden terdapat 26 orang atau 34,66 persen memiliki pendapatan diantara Rp 1.000.000,- Rp. 2.000.000,-. 38 orang atau 50,66 persen memiliki pendapatan diantara $\mathrm{Rp} 2.100 .000$,- $\mathrm{Rp}$. 3.000.000,-. 9 orang atau 12,00 persen memiliki pendapatan diantara Rp 3.100.000,Rp. 4.000.000,-. Dan 2 orang atau 2,66 persen memiliki pendapatan diantara Rp 4.100.000,- Rp. 5.000.000. Berdasarkan rata-rata pendapatan yang diterima oleh responden maka kondisi ekonomi masyarakat tersebut berada pada kondisi ekonomi yang cukup, oleh karena itu, perlunya dorongan pemerintah dalam memerhatikan tingkat ekonomi masyarakat di perdesaan agar mampu berkembang dan meningkatkan kesejahteraan ekonomi keluarga di perdesaan khususnya di Desa Betung Bedarah Timur Kecamatan Tebo Ilir Kabupaten Tebo. 


\section{Faktor - faktor yang mempengaruhi lamanya mencari pekerjaan di Desa Betung Bedarah Timur Kecamatan Tebo Ilir}

Analisis ini dilakukan untuk mengetahui seberapa besar pengaruh dari variabel independen yang meliputi pendapatan responden, usia, gaji, pendidikan terakhir dan jenis kelamin yang mempengaruhi lamanya menganggur sebagai variabel dependen di Desa Betung Bedarah Timur Kecamatan Tebo Ilir Kabupaten Tebo. Jumlah data yang di gunakan sebanyak 75 responden yaitu responden yang bekerja yang sudah berkeluarga, diperoleh melalui survey dan dianalisis secara deskriftip kuantitatif serta untuk melihat pengaruh setiap variabel digunakan metode analisis regresi linier berganda maka di peroleh hasil sebagai berikut:

Tabel 6. Hasil persamaan regresi linier berganda

\begin{tabular}{crrrr}
\hline \hline \multicolumn{1}{c}{ Variable } & Coefficient & Std. Error & t-Statistic & Prob. \\
\hline \hline C & 19.56874 & 8.508496 & 2.299906 & 0.0244 \\
USIA & 0.359278 & 0.155811 & 2.305863 & 0.0241 \\
GAJI & $1.03 \mathrm{E}-06$ & $1.09 \mathrm{E}-06$ & 0.939795 & 0.3506 \\
PDD & -1.533891 & 0.487450 & -3.146767 & 0.0024 \\
JK & 1.307011 & 2.177165 & 0.600327 & 0.5502 \\
\hline \hline R-squared & 0.594307 & Mean dependent var & 12.41333 \\
Adjusted R-squared & 0.553981 & S.D. dependent var & 7.904999 \\
S.E. of regression & 6.827735 & Akaike info criterion & 6.744203 \\
Sum squared resid & 3263.257 & Schwarz criterion & 6.898703 \\
Log likelihood & -247.9076 & Hannan-Quinn criter. & 6.805893 \\
F-statistic & 7.298311 & Durbin-Watson stat & 1.305592 \\
Prob(F-statistic) & 0.000057 & & & \\
\hline \hline
\end{tabular}

Sumber: Data diolah, 2019

Berdasarkan Tabel 6 Dari hasil estimasi di atas dapat dituliskan persamaaan sebagai berikut :

$\mathrm{Y}=19.56874+0.359278$ Usia + 0.000103 Gaji - 1.533891 PDD + 1.307011 JK

Dari hasil tersebut kemudian dilakukan uji statistik dan uji asumsi klasik.

Berdasarkan hasil faktor umur memiliki nilai koefisien regresi sebesar 0.359278 artinya setiap bertambah satu tahun umur responden, maka lamanya mencari pekerjaan meningkat sebesar 0.359278 tahun. Selain itu, faktor gaji responden memiliki nilai koefisien regresi sebesar 0.000103 artinya setiap bertambah satu persen gaji responden, maka lamanya mencari pekerjaan meningkat sebesar 0.000103 tahun. Pendidikan memiliki nilai koefisien regresi sebesar 1.533891 artinya setiap bertambah satu tahun pendidikan responden, maka lamanya mencari pekerjaan menurun sebesar 1.533891 tahun. Jenis kelamin memiliki nilai koefisien sebesar 1.307011 artinya jika jenis kelamin meningkat satu orang maka lamanya mencari pekerjaan meningkat sebesar 1.307011 tahun.

Uji asumsi klasik 


\section{Multikolinieritas}

Multikolinearitas muncul ketika terjadi hubungan linier antara variabel independent baik dalam bentuk linier yang sempurna maupun hubungan linier yang kurang sempurna. Ketika terjadi hubungan antara variabel independent dalam suatu model regresi, masalah multikolinearitas akan tetapi akan hubungan dengan asumsi variabel gangguan untuk mendeteksi adanya multikolinearitas dalam model persamaan pada penelitian ini digunakan korelasi antara variabel independent. Nilai koefisien antar variabel dilihat melalui Tabel 7 berikut ini:

Tabel 7. Uji multikolinearitas

\begin{tabular}{ccccc}
\hline Variabel & Usia & Gaji & PDD & JK \\
\hline Usia & 1.00000 & 0.35669 & -0.09572 & 0.21247 \\
Gaji & 0.35669 & 1.00000 & -0.14085 & 0.31116 \\
PDD & -0.09572 & -0.14085 & 1.00000 & -0.48926 \\
JK & 0.21247 & 0.31116 & -0.48926 & 1.00000
\end{tabular}

Sumber : Data diolah, 2019

Berdasarkan tabel 7 nilai koefisien korelasi setiap variabel usia, gaji, pendidikan dan jenis kelamin bahwa nilai korelasi yang tidak melebihi 0.594307 mengidentifikasikan bahwa tidak terjadi nya multikolinearitas yang serius.

\section{Heteroskedasitas}

Untuk mendeteksi gejala heteroskedaksitas dalam model ini digunakan uji heteroskedasitas dengan metode White tanpa Cross Terms dan Metode White dengan Cros Terms. Hasil uji heteroskedasitas dengan metode White tanpa Cross Terms dapat dilihat melalui tabel berikut ini:

Tabel 8. Uji heteroskedasitas

Heteroskedasticity Test: White

\begin{tabular}{llll}
\hline \hline F-statistic & 0.985941 & Prob. F(13,61) & 0.4755 \\
Obs*R-squared & 13.02260 & Prob. Chi-Square(13) & 0.4461 \\
Scaled explained SS & 24.63675 & Prob. Chi-Square(13) & 0.0258 \\
\hline
\end{tabular}

Sumber : Data diolah, 2019

Dari hasil test pada table 8 Nilai Chi Square (X) hitung 13.02260 diperoleh dari informasi Obs*R-Square. Sementara nilai kritis Chi Square $\left(\mathrm{X}^{2}\right)$ pada $\alpha=0.05$ persen dengan df 4 adalah sebesar 91.67024 hal ini menunjukan bahwa Chi-Square hitung (X) $>$ Chi-Square Tabel $(\mathrm{X})$ atau $13.02260<91.67024$, maka dapat disimpulkan tidak terdapat heteroskedasitas. Dan dapat dilihat juga dari nilai Probabilitasnya Chi-Square sebesar $0.4461>0.05$ persen yang berarti signifikan.

\section{Autokorelasi}

Autokorelasi menunjukkan adanya hubungan antar gangguan. Metode yang digunakan dalam mendeteksi ada tidaknya masalah autokorelasi adalah Metode Bruesch-Godfrey yang lebih dkenal dengan LM-Test. Metode ini didasarkan pada nilai F dan $O b s * R$-Squared. Dimana jika nilai probabilitas dari $O b s^{*} R$-Squared melebihi tingkat kepercayaan maka Ho diterima, berarti tidak ada masalah autokorelasi. Dapat dilihat dari hasil estimasi sepertinya tidak terjadi permasalahan yang melanggar asumsi 
klasik. Dimana terlihat bahwa nilai t-statistik signifikan., $\mathrm{R}^{2}$ bagus, dan Uji $\mathrm{F}$ juga signifikan. Namun dalam hasil tersebut terdapat DW stat yang relatif kecil. Nilai DW yang kecil tersebut merupakan salah satu indikator adanya masalah autokorelasi. Untuk membuktikan adanya masalah autokorelasi dalam model dapat kita lakukan dengan melakukan uji LM. Sebagai berikut:

Tabel 9. Uji autokorelasi

Breusch-Godfrey Serial Correlation LM Test:

\begin{tabular}{llll}
\hline \hline F-statistic & 2.077342 & Prob. F(4,66) & 0.0937 \\
Obs*R-squared & 8.386594 & Prob. Chi-Square(4) & 0.0784 \\
\hline
\end{tabular}

Sumber: Data diolah, 2019

Dari hasil test table 9 diatas dapat disimpulkan bahwa dalam hasil estimasi tersebut tidak terjadi masalah autokorelasi. Hal ini dapat dilihat dari nilai probabilitas lebih dari tingkat keyakinan ( $\alpha=0.05$ persen) atau nilai chi-square $0.0784>0.05$ maka Ho diterima dan Ha menolak yang berarti dalam model tidak terdapat autokorelasi.

\section{Koefisien determinasi}

Uji ini digunakan untuk mengetahui berapa persen variasi variabel dependen yang bisa dijelaskan variabel independen. Dari hasil regresi diketahui bahwa nilai $\mathrm{R}^{2}$ adalah 0.594307 sehingga dapat katakan bahwa 59.43 persen lamanya menganggur di Desa Betung Bedarah Timur Kecamatan Tebo Ilir Kabupaten Tebo dijelaskan oleh variabel usia, gaji, pendidikan dan jenis kelamin. Sedangkan sisanya 40.57 persen di jelaskan faktor lain diluar penelitian.

\section{Uji hipotesis}

\section{Uji F statistik (secara bersama-sama)}

Demikian uji f statistik dengan jumlah 75 responden dengan tingkat signifikansi sebesar 95 persen maka di ketahui nilai probabilitas f statistik sebesar $0.000057<0.05$ persen, maka Ho ditolak dan Ha di terima. Artinya bahwa semua koefisien regresi atau semua variabel independen yaitu usia, gaji, pendidikan dan jenis kelamin secara bersama - sama berpengaruh terhadap lamanya menganggur di Desa Betung Bedarah Timur Kecamatan Tebo Ilir Kabupaten Tebo.

\section{Uji t statistik ( secara individual)}

Berdasarkan hasil persamaan regresi di dapat hasil uji t statistik, yaitu untuk melihat pengaruh secara individual pada setiap variabel sebagai berikut. Tingkat signifikansi sebesar 95 persen maka di ketahui nilai probabilitas $\mathrm{t}$ statistik sebesar $0.0241<0.05$ persen, maka Ho ditolak dan Ha di terima artinya variabel usia berpengaruh signifikan terhadap lamanya menganggur di Desa Betung Bedarah Timur Kecamatan Tebo Ilir Kabupaten Tebo. Tingkat signifikansi sebesar 95 persen maka di ketahui nilai probabilitas t statistik sebesar $0.3506>0.05$ persen, maka Ho diterima dan Ha di tolak artinya variabel gaji tidak berpengaruh signifikan terhadap lamanya menganggur di Desa Betung Bedarah Timur Kecamatan Tebo Ilir Kabupaten Tebo. Tingkat signifikansi sebesar 95 persen maka di ketahui nilai probabilitas t statistik sebesar $0.0024<0.05$ persen, maka Ho ditolak dan Ha di terima artinya variabel pendidikan terakhir berpengaruh signifikan terhadap lamanya menganggur di Desa 
Betung Bedarah Timur Kecamatan Tebo Ilir Kabupaten Tebo. Tingkat signifikansi sebesar 95 persen maka di ketahui nilai probabilitas $t$ statistik sebesar $0.5502>0.05$ persen, maka Ho diterima dan $\mathrm{Ha}$ di tolak artinya variabel jenis kelamin tidak berpengaruh signifikan terhadap lamanya menganggur di Desa Betung Bedarah Timur Kecamatan Tebo Ilir Kabupaten Tebo.

\section{KESIMPULAN DAN SARAN}

\section{Kesimpulan}

Karakteristik penduduk responden di Desa Betung Bedarah Timur Kecamatan Tebo Ilir Kabupaten Tebo menurut usia rata - rata usia 28 tahun, pada tingkat pendidikan rata - rata lulusan sekolah menengah atas, menurut status pekerjaan banyak memiliki buruh tetap, jenis pekerjaan terbanyak buruh dan pendapatan $\mathrm{t}$ rata - rata sekitar Rp. 2.548.000. Berdasarkan hasil penelitian dengan menggunakan statistik yaitu untuk melihat pengaruh secara uji silmultan yaitu semua variabel usia, gaji, pendidikan dan jenis kelamin secara bersama - sama berpengaruh terhadap lamanya menganggur di Desa Betung Bedarah Timur Kecamatan Tebo Ilir Kabupaten Tebo. Jika di uji secara parsial variabel yang memiliki pengaruh adalah usia dan pendidikan berpengaruh signifikan terhadap lamanya menganggur di Desa Betung Bedarah Timur Kecamatan Tebo Ilir Kabupaten Tebo, sedangkan variabel gaji dan jenis kelamin tidak berpengaruh signifikan terhadap lamanya menganggur di Desa Betung Bedarah Timur Kecamatan Tebo Ilir Kabupaten Tebo.

\section{Saran}

Dalam mencegah lamanya menganggur responden harus mampu menghilangkan rasa gengsi yang ada untuk memperoleh sebuah pekerjaan, karena gengsi pekerjaan yang didapatkan tidak menentukan karier di masa depan dan tentu saja kerja keras merupakan hasil terbaik dalam perkembangan karir. Untuk menekan angka pengangguran secara merata seharusnya pemerintah menyiapkan lapangan kerja disetiap kabupaten, jadi tenaga kerja tidak perlu mencari kerja ke luar daerah. Serta pemerintah meningkatkan upaya memberikan kesiapan para lulusan baru menghadapi dunia kerja, serta Upahnya disesuaikan dengan kabupaten.

\section{DAFTAR PUSTAKA}

Amir, Amri. (2007). Perekonomian Indonesia (Dalam Perspektif Makro). Biografika. Bogor.

Amir. Amri,.Junaidi dan Yulmardi (2009). Buku Metodologi Penelitian Ekonomi dan Penerapannya. IPB PRESS :Bogor.

Badan Pusat Statistik Badan Pusat Statistik (2019). Keadaan Angkatan Kerja di

Provinsi Jambi dalam http://jambi.bps.go.id Tanggal 10 Oktober 2019

Gujarati. Damodar (2003). Buku Economectric. Erlangga :Jakarta.

Kuncoro, Mudrajad. (2006). Strategi: Bagaimana Meraih Keunggulan Kompetitif . Erlangga :Jakarta.

Badan Pusat Statistik Badan Pusat Statistik (2019).. Kecamatan Tebo Ilir Dalam Angka 2014 - 2017, Kabupaten Tebo.

Mulyadi Subri, (2003). Ekonomi Sumber Daya Manusia, PT Raja Grafindo Persada Jakarta.

Mankiw N,Gregory. (2006). Makro Ekonomi, Terjemahan: Fitria Liza, Imam Nurmawan, Erlangga :Jakarta. 
Novianti. Endah (2018) Skripsi Kesenjangan Tingkat Pengangguran Terbuka Di Indonesia.Universitas Negeri Yogyakarta :Yogyakarta.

Sukirno, Sadono. (2006). Makroekonomi Teori Pengantar. PT.Rajagrafindo Persada Jakarta.

Simanjuntak, Payaman J. (2001), Buku Pengantar Ekonomi Sumber Daya Manusia, LembagaPenerbit Universitas Indonesia :Jakarta.

Sumarsono, Sonny. (2003). Ekonomi Manajemen Sumber Daya Manusia dan Ketenagakerjaan. Graha Ilmu : Yogyakarta.

Sugiyono. (2016). Buku Metode Penelitian Kuantitatif, Kualitatif dan R\&D. CV. Alfabeta : Bandung.

Yuliatin, Tun Huseno, dan Febriani (2011). Pengaruh Karakteristik Kependudukan Terhadap Pengangguran di Sumatera Barat". Jurnal Manajemen dan Kewirausahaan, 2(2), Mei 2011 ISSN : 2086 - 5031. Universitas Tamansiswa Padang 